\title{
Study on Preparation of Bio-Oil from Wheat Straw by Hydrothermal Liquefaction
}

\author{
Dongyu Guo, Jun Wang* \\ Department of Chemistry and Chemical Engineering, Zhoukou Normal University, Henan, China \\ Email: ${ }^{\star}$ zk-wangjun@163.com
}

How to cite this paper: Guo, D.Y. and Wang, J. (2020) Study on Preparation of Bio-Oil from Wheat Straw by Hydrothermal Liquefaction. Open Access Library Journal, 7: e6500.

https://doi.org/10.4236/oalib.1106500

Received: June 3, 2020

Accepted: June 25, 2020

Published: June 28, 2020

Copyright $\odot 2020$ by author(s) and Open Access Library Inc.

This work is licensed under the Creative Commons Attribution International License (CC BY 4.0).

http://creativecommons.org/licenses/by/4.0/

(c) (i) Open Access

\begin{abstract}
Wheat straw is an ideal green renewable resource, which is widely used as fertilizers, feedstuffs, edible funguses, industrial raw materials and fuels. Hydrothermal liquefaction of biomass that works under normal or slightly pressurized conditions results in higher oil quality. We summarize the technical principles of hydrothermal liquefaction, analyze the difficulties and problems in the utilization of various technologies, and put forward the development trend of promoting the application of biomass energy to high value-added industrial raw materials.
\end{abstract}

\section{Subject Areas}

Agricultural Science, Biochemistry, Bioengineering

\section{Keywords}

Wheat Straw, Biomass Recycling, Bio-Oil, Hydrothermal Liquefaction

\section{Introduction}

China, as a traditional large agricultural country, has abundant crop straw reserves, mainly including wheat straw and corn straw. According to incomplete statistics, the output of crop straws in China in 2015 and 2018 reached 850 million tons and 870 million tons respectively. It is estimated that the market size of China's straw waste treatment industry will reach about 332.9 billion yuan in 2018. With the continuous improvement of utilization rate and technical level of straw waste treatment in China, the market scale of straw waste treatment industry is expected to continue to increase slowly in the future.

In terms of application trends, the trend of comprehensive utilization of straw resources in China is reflected in the increase in the utilization of straw new 
energy development, straw feeding consumption, straw industrial processing consumption, straw edible fungus cultivation consumption, straw waste and burning amount, and straw direct burning amount. In addition, straw return to the field, straw mulch fertilizer return to the field and straw mulch fertilizer return to the field gradually replace straw direct return to the field. It is estimated that by 2020 , the comprehensive utilization rate of straw in China will reach more than $85 \%$.

In this paper, we summarize the reviews of usages of hydrothermal liquefaction method in biomass recycling especially in wheat straw area.

\section{Discussion}

\subsection{Comprehensive Utilization Status of Straw}

Crop straw is an important by-product of crops and the largest renewable resource on the earth. It is rich in nutrients and usable chemical components and can be used as fertilizer, feed, household fuel and industrial and sideline raw materials. Crop straw is mainly composed of cellulose, hemicellulose and lignin. The organic components of straw are mainly cellulose and hemicellulose, followed by lignin, protein, amino acid, etc. The comprehensive utilization technology catalogue of straw prepared and released by the national development and reform commission and the ministry of agriculture puts forward five utilization methods of straw resources, including fertilizer, feed, raw material, base material and fuel.

\subsection{The Definition and Advantages of Hydrothermal Liquefaction Technology}

Since the 1970s, the utilization of biomass energy has been attached great importance to by all countries in the world. Biomass liquefaction in water is one of the most attractive utilization methods of biomass. Hydrothermal liquefaction technology is a process of obtaining liquid products from biomass under certain pressure and temperature with water as solvent, which mainly includes indirect liquefaction and direct liquefaction. Indirect liquefaction is referred to the gasification of biomass into gas at the first step, then further synthesis of liquid products; Or, the cellulose in biomass is changed hemicellulose into polysaccharides by hydrolysis method, then biotechnology fermentation into alcohol [1]. Because this kind of technical route is more multifarious, the applied range is less.

Direct liquefaction is a technology in which biomass is mixed with a certain amount of solvent in an autoclave vacuums or inlet protective gas, and biomass is converted into fuel or chemical under appropriate temperature and pressure (a certain amount of catalyst can be added if necessary). In recent years, direct liquefaction of biomass has been reported increasingly. Compared with the other thermochemical transformation of biomass, direct liquefaction has the characteristics of mild reaction conditions, easy operation and easy realization, and has certain economic value. So, more and more attention has been paid to it. 


\subsection{Application of Hydrothermal Liquefaction Method in Biomass Recycling}

The study of biomass liquefaction has flourished since fierz-david transformed wood and cellulose into a liquid in 1925. In the early 1970s, Appell et al. [2] in the United States carried out a lot of pioneering research on biomass liquefaction and became the pioneer in this field. Beckman et al. [3] took distilled water as solvent, used $\mathrm{H}_{2}(10 \mathrm{MPa})$ and $\mathrm{Ni}$ as reducing agent, and liquefied Populus Deltoides at $350^{\circ} \mathrm{C}$, with the reaction time of 2 hours in 1980s. More and more scholars put into the study of biomass liquefaction, they investigate the influence of various factors on liquefaction, such as raw materials, temperature, time, pressure, catalysts, reaction media, etc., and explore the establishment of liquefaction model. In the process of direct liquefaction, the increase of liquefaction products and the properties of liquid products can be improved by changing the solvent and liquefaction conditions, adding catalysts and hydrogen, etc.

Minowa et al. [4] investigated the reaction behavior of cellulose in the range of $200^{\circ} \mathrm{C}-350^{\circ} \mathrm{C}$ in high pressure water without catalyst and analyzed the product distribution. The experiment found that cellulose began to decompose at about $200^{\circ} \mathrm{C}$, the reaction was accelerated at about $240^{\circ} \mathrm{C}-270^{\circ} \mathrm{C}$, and the cellulose reaction was basically complete at $280^{\circ} \mathrm{C}$. Demirbas [1] used anhydrous glycerin as solvent and $\mathrm{Na}_{2} \mathrm{CO}_{3}$ or $\mathrm{KOH}$ as catalyst for biomass liquefaction, while the liquefaction temperature was investigated.

\subsection{The New Focus of Hydrothermal Liquefaction Method in Biomass Recycling}

The development of high quality and low price non-grain biomass raw materials and its efficient and scientific conversion technology is the premise and basis for the large-scale development of biofuels, and it is of great practical and long-term significance for the sustainable development of human society to protect the ecological environment.

Aquatic plants, as an important renewable biomass, are characterized by their wide distribution, high photosynthetic efficiency, strong environmental adaptability and short growth cycle. The research focuses on the preparation of aquatic plant biofuels.

Brown et al. studied the non-catalytic gas and liquefaction behavior of microalgae in supercritical/subcritical water. Under the reaction condition of $350^{\circ} \mathrm{C}$ and $1 \mathrm{~h}$, the yield of the obtained liquefied oil can reach $43 \mathrm{wt} \%$. Duan et al. [5] studied the effects of different types of heterogeneous catalysts on the liquefaction behavior of microalgae in subcritical water. It is found that the introduction of catalysts can increase the yield of liquefied oil in either inert or reductive atmosphere, but the presence of catalysts and the type of catalysts have little effect on the yield of liquefied oil and the content of each element. Chen hanping's research group from huazhong university of science and technology selected rice stalks, water hyacinth, cellulose and xylan as raw materials, and conducted hydrothermal $\left(300^{\circ} \mathrm{C}, 30 \mathrm{~min}\right)$ and hydrothermal carbonization $\left(220^{\circ} \mathrm{C}, 4 \mathrm{~h}\right)$ stu- 
dies in the intermittent reaction kettle, and made comparative analysis on the products obtained from the two different types of reactions. The results showed that $21.62 \mathrm{wt} \%$ heavy oil yield could be obtained from rice stalks, while 15.00 , 11.61 and $12.19 \mathrm{wt} \%$ heavy oil yield could be obtained from cellulose and water hyacinth xylan, respectively.

\section{Conclusion}

Hydrothermal process is an effective way to produce liquefied oil from aquatic biomass. Although the method is simple to operate, the separation of liquefied oil is complicated, and the content of nitrogen, sulfur and oxygen is high, the viscosity is large, the calorific value is low, so it cannot be used directly. But its low grade, the high oxygen content, moisture content is higher, low $\mathrm{pH}$ value, density is larger than water, calorific value is equivalent to $40 \%$ of the same quality of gasoline or diesel, viscosity range is very large, poor stability, corrosive and other shortcomings. Many scholars at home and abroad have done a lot of research on improving conversion efficiency of direct liquefaction of biomass and inhibiting reckoning, so that it can be used more widely.

\section{Acknowledgement}

This paper is supported by Research and Innovation Fund for college students of Department of Chemistry and Chemical Engineering of Zhoukou Normal University (No. HYDC202002).

\section{Conflicts of Interest}

The authors declare no conflicts of interest regarding the publication of this paper.

\section{References}

[1] Demirbs, A. (2000) Mechanisms of Liquefaction and Pyrolysis Reactions of Biomass. Energy Concersion \& Management, 41, 633-646. https://doi.org/10.1016/S0196-8904(99)00130-2

[2] Appell, H.R., Fu, Y.C., Frideman, S., et al. (1971) Converting Organic Wastes to Oil: A Replenishable Energy Source. U.S. Bureau of Mines, Washington, D.C.

[3] Beckman, D. and Boocock, D.G. (1983) Liquefaction of Wood by Rapid Hydropyrolysis. The Canadian Journal of Chemical Engineering, 61, 80-86. https://doi.org/10.1002/cjce.5450610114

[4] Minowa, T., Fang, Z., Ogi, F. and Várhegyi, G. (1998) Decomposition of Cellulose and Glucose in Hot Compressed Water under Catalyst-Free Condition. Journal of Chemical Engineering of Japan, 31, 131-134.

[5] Xu, Y., Duan, P. and Wang, F. (2015) Hydrothermal Processing of Macroalgae for Producing Crude Bio-Oil. Fuel Processing Technology, 130, 268-274. https://doi.org/10.1016/j.fuproc.2014.10.028 